\title{
Toxicity of Muscle and Other Organs of Five Species of Puffer Collected from the Pacific Coast of Tohoku Area of Japan
}

\author{
Masaaki Kodama, ${ }^{* 1}$ Takehiko Ogata, ${ }^{* 1}$ Kazuo KaWAMUKaI,*2 \\ Yasukatsu OsHImA, ${ }^{* 3}$ and Takeshi YasUMOTO*3 \\ (Accepted August 11, 1983)
}

\begin{abstract}
Analyses of tetrodotoxin content were carried out on the following five species of puffer fish collected from Pacific coast of Tohoku area of Japan: Takifugu pardalis, T. poecilonotus, $T$. porphreus, $T$. vermicularis, and $T$. stictonotus. The toxin contents in the muscle of $T$. poecilonotus were frequently higher than $50 \mathrm{MU} / \mathrm{g}$, with the highest of $350 \mathrm{MU} / \mathrm{g}$ and most of the specimens with high muscle toxicity were female. Lethality of the muscle in other four species was less significant, with the exception of a few specimens of $T$. paradalis. Toxin concentration in the liver and ovary of two species, $T$. poecilonotus and $T$. pardalis, were extremely high. The highest value $40,000 \mathrm{MU} / \mathrm{g}$ was found in the liver of $T$. pardalis. In contrast, the same organs of the deeper dwellant $T$. porphreus were less toxic. The results of this study point out to the need to pay a special attention for the commercial use of $T$. poecilonotus.
\end{abstract}

Puffer fish are of special importance in Japan from a stand point of public health because more than 50 people are intoxicated every year and fatalities due to puffer poisoning account for over $60 \%$ of those of all food poisoning.

Out of 29 Japanese puffer, 13 species are commonly used for food. Among them, torafugu Takifugu rubripes, karasu $T$. chinensis, mafugu $T$. porphreus, shosaifugu $T$. vermicularis and nashifugu $T$. radiatus are the popular species. However, decreasing catch of these species in recent years have been attracting other species to the market.

The most extensive study conducted by $\mathrm{TANI}^{12}$ on Japanese puffers indicates that the ovary and liver, in general, are most highly and most frequently toxic. The skin and intestine are moderately toxic, with few exception. The testis and muscle are considered as either weakly toxic or non-toxic, hence, safe for consumption. Recent study of MATSur et al. ${ }^{27}$ on the liver and ovary of $T$. niphobles, however, reveals the presence of a marked regional variation of toxicity within the same species. No comparable study, however, exists on the regional variation of muscle toxicity. Since most of the specimens tested by TANI ${ }^{1)}$ were collected from southern part of Japan, there is a question whether the current criteria given by TANl for safety consumption of puffers can be applicable to puffers in other parts of Japan. As a first step to answer the question, we started testing of puffers in Tohoku area, where practically no data existed in the past on the local puffers.

In this paper, we report the tetrodotoxin (TTX) contents in the muscle, liver and ovary of five species of puffer caught in Tohoku area, with an emphasis on frequent occurrence of considerably high level of toxin in the muscle of $T$. poecilonotus.

\section{Materials and Methods}

\section{Materials}

Four species of puffer were collected from Okkirai Bay, Sanriku, Iwate Prefecture, between June and December, and four species from Okatsu Bay, Miyagi Prefecture, on August 15, 1982. Eighty-four specimens of higanfugu Takifugu pardalis, 57 of komonfugu T. poecilonotus, 9 of mafugu $T$, porphreus, 11 of shosaifugu $T$, vermicularis, 3 of gomafugu $T$. stictonotus were used for analyses.

Assay

The viscera removed from live specimens were

*1 Laboratory of Marine Biological Chemistry, School of Fisheries Science, Kitasato University, Sanriku, Iwate 022-01, Japan（児玉正炤・緒方武比古：北里大学水産学部）。

*2 Miyakuro Health Center, Tori, Sendai, Miyagi 980, Japan (/川向和雄：宫城棏宮黑保健所).

*3 Faculty of Agriculture, Tohoku University, Tsutsumi-dori, Sendai, Miyagi 980, Japan (大島泰克 - 安元 健: 東北大学题学部). 
further dissected into the livers, ovaries and testes. The muscle was taken from the area between anus and caudal fin with caution to avoid contaimination with the skin. These tissue samples were analyzed immediately after dissection or after storage at $-80^{\circ} \mathrm{C}$.

Dilute acetic acid $(0.03 \mathrm{~N})$ was added to one gram of each tissue sample to make up the total volume to $2 \mathrm{ml}$ and the mixture was homogenized for a short period. The homogenate was further sonicated for $2 \mathrm{~min}$ and centrifuged at 3,000 rpm for $10 \mathrm{~min}$. One $\mathrm{ml}$ of supernatant thus obtained was assumed to contain TTX from $0.5 \mathrm{~g}$ of the tissue. The solution, intact or after adequate dilution, was injected into mice intraperitoneally. The lethal potency was calculated from KAWABATA's table ${ }^{9)}$ for dose-survival time relationship for TTX, which defines 1 mouse unit (MU) as a dose required to kill a $20 \mathrm{~g}$ male mouse at $30 \mathrm{~min}$.

\section{Results}

\section{Toxicity of the Muscle}

Fig. 1 shows the TTX contents in the muscle of puffers caught in Okkirai Bay. In T. pardalis, $87 \%$ showed lethality below $10 \mathrm{MU} / \mathrm{g}, 8 \%$ between $10-20 \mathrm{MU} / \mathrm{g}$, and $5 \%$ between 20 and $40 \mathrm{MU} / \mathrm{g}$. On the other hand, nearly $90 \%$ of $T$. poecilonotus contained TTX over $10 \mathrm{MU} / \mathrm{g}$, with more than $20 \%$ of muscle specimens over $50 \mathrm{MU} / \mathrm{g}$. The highest TTX concentration recorded was 350 $\mathrm{MU} / \mathrm{g}$. It is interesting to note that the most of $T$. poecilonotus specimens showing such high toxin levels were female. The same tendency was even more evident in the samples from Okatsu as shown in Fig. 2. All the muscle of both $T$. pardalis and $T$. poecilonotus from Okatsu contained TTX over $10 \mathrm{MU} / \mathrm{g}$. But the TTX content of the former was less significant than the latter species, in which $50 \%$ of the specimens showed toxicity over $50 \mathrm{MU} / \mathrm{g}$. Toxicity of other three species seemed insignificant. For example, 4 of 9 specimens of $T$. porphreus were non-lethal to mouse and TTX contents in the remaining 5 were below $10 \mathrm{MU} / \mathrm{g}$. These results show that the distinct difference exists among species in the frequency of higly toxic muscle.

\section{Toxicity of Liver and Ovary and Relation of Toxicity among Organs}

Figs. 3 and 4 respectively show the toxicity of liver and ovary of the specimens collected from

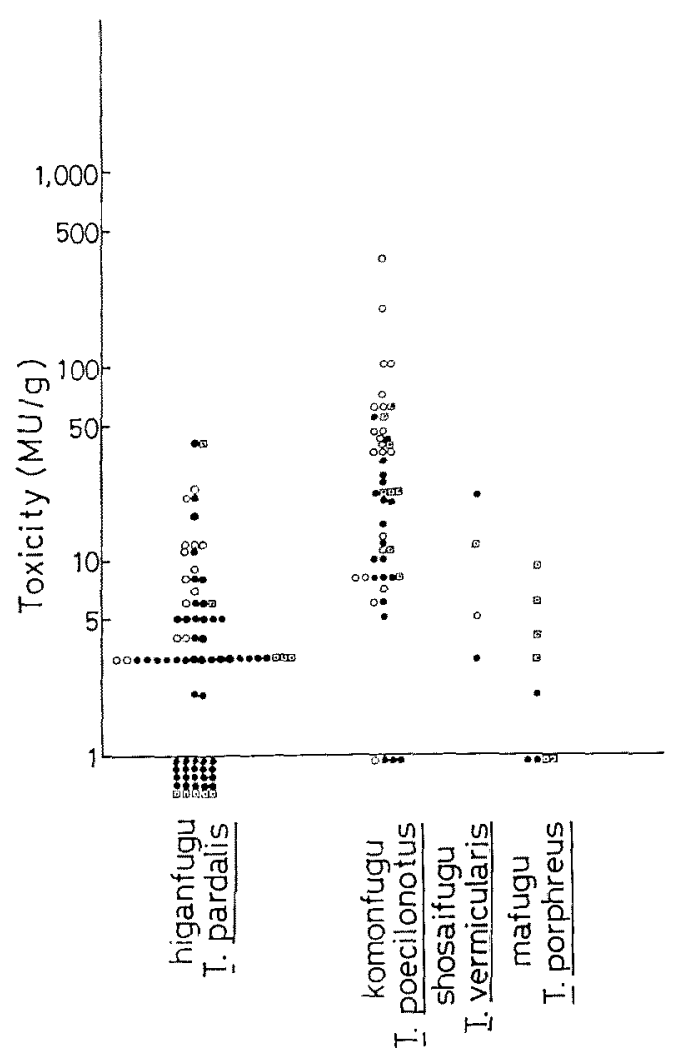

Fig. 1. Tetrodotoxin content in the muscle of puffer specimens collected from Okkirai Bay in 1982. - : male, $O$ : female, $\square$ : not identified.

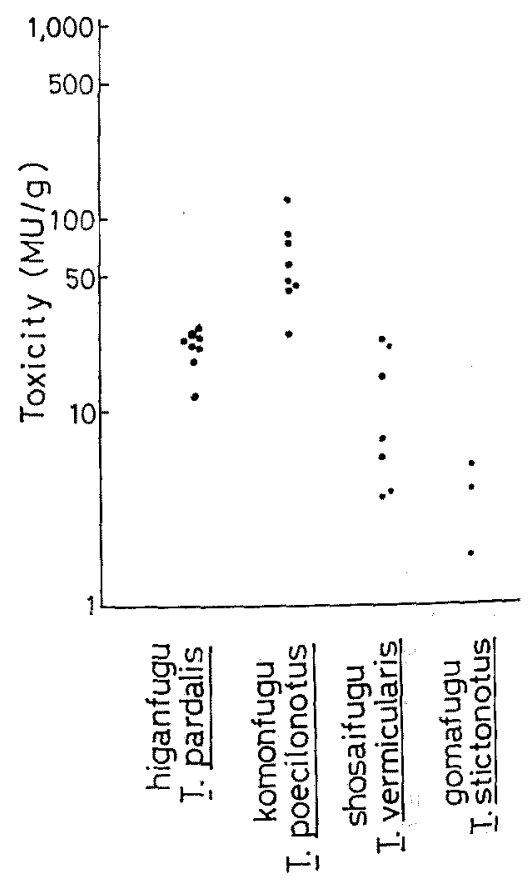

Fig. 2. Tetrodotoxin content in the muscle of puffer specimens collected from Okatsu Bay in 1982. 


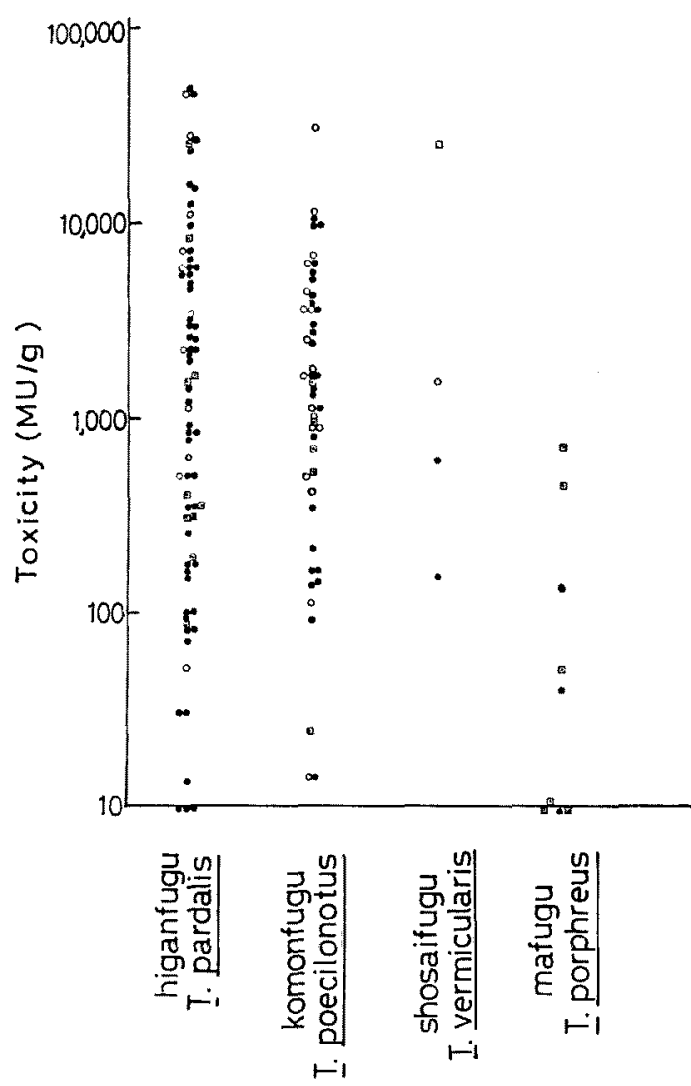

Fig. 3. Tetrodotoxin content in the liver of puffer specimens collected from Okkirai Bay in 1982. : male, $\bigcirc$ : female, $\square$ : not identified.

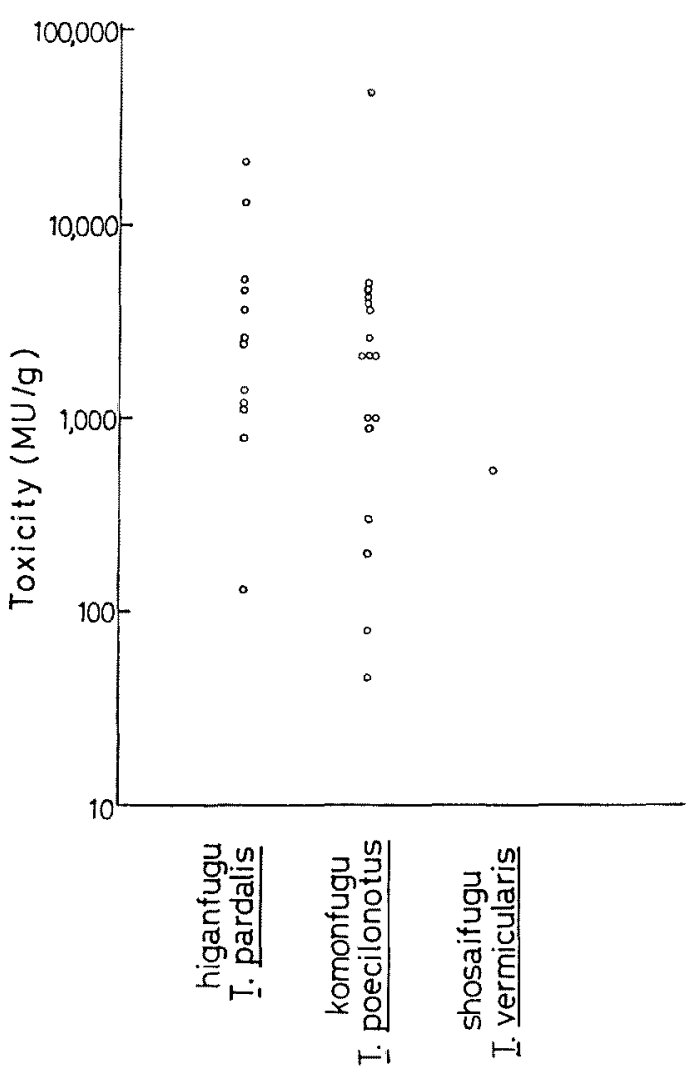

Fig. 4. Tetrodotoxin content in the ovary of puffer specimens collected from Okkirai Bay in 1982.

Table 1. Correlation coefficients of the toxin contents between muscle and liver, muscle and ovary, and liver and ovary

\begin{tabular}{lllll}
\hline \hline & Higanfugu & Komonofugu & Shosaifugu & Mafugu \\
& $T$. pardalis & $T$. poecilonotus & $T$. vermicularis & $T$. porphreus \\
Muscle and liver & $0.16(\mathrm{~N}=77)$ & $0.30(\mathrm{~N}=49)$ & $0.12(\mathrm{~N}=4)$ & $0.09(\mathrm{~N}=9)$ \\
Muscle and ovary & $0.18(\mathrm{~N}=12)$ & $0.13(\mathrm{~N}=17)$ & - & - \\
Liver and ovary & $0.64(\mathrm{~N}=12)$ & $0.02(\mathrm{~N}=17)$ & - & - \\
\hline
\end{tabular}

Okkirai. The toxin contents in $T$. pardalis, $T$. poecilonotus, and $T$. vermicularis were much higher than those reported by TAN $^{12}$ especially in the liver. In the case of $T$. pardalis, $20 \%$ of specimens contained the toxin over $5,000 \mathrm{MU} / \mathrm{g}$, with the highest of $40,000 \mathrm{MU} / \mathrm{g}$. YаMAMORI and TASAKA* also reported high toxicity of the livers of these two species collected from Okkirai Bay in 1981. On the other hand, the livers of $T$. porphreus, the deeper dwellant, were less toxic than those of other 3 species. The toxin contents were within the range of reported value. ${ }^{1)}$

In Table 1, correlation coefficients of the toxicity values between muscle and liver, muscle and ovary, and liver and ovary are shown. No relationship was recognized between them.

\section{Discussion}

From public health point of view, a special attention should be paid to the fact that TTX content in the muscle of $T$. poecilonotus frequently

* K. Yamamori and R. TASaKa: The Abstracts of Oral Presentation of the Autumn Meeting of Japan. Soc. Sci. Fish., p. 131 (1982). 
exceeded $50 \mathrm{MU} / \mathrm{g}$. Since up to $200 \mathrm{~g}$ of the muscle was served for one person at restaurants,") use of this species for food is extremely dangerous in view of the fact that ingestion of $10,000 \mathrm{MU}$ ( $2 \mathrm{mg}$ ) of TTX is lethal to an adult. ${ }^{1)}$ As some people might eat more than $200 \mathrm{~g}, T$. paradalis should be also avoided. Because the toxicity varies locally, seasonally and individually, more expanded study is needed to ensure safety consumption of puffers.

\section{Acknowledgements}

We are very grateful to Messers. H. OHNo and H. SArto for their technical assistance and to the Okkirai Fisheries Cooperative Association for the supply of the puffer specimens used. Our thanks are also due to Associate Professor H. IDA, School of Fisheries Sciences, Kitasato University, for identification of the puffers.

\section{References}

1) I. TANI: Toxicological Studies in Japanese Puffers, Teikoku Tosho, Tokyo, 1945, pp. 103.

2) T. Matsui, S. Hamada, and K. Yamamori: Bull. Japan. Soc. Sci. Fish., 48, 1179 (1982).

3) T. Kawabata: "in The Manual for the Methods of Food Sanitation Tests (Shokuhin Eisei Kensa Shishin) II", Japan Food Hygienic Association, Tokyo, 1978, pp. 232-240.

4) M. Ito and M. KaINuma: Food Sanitation Research, 12, 87-89 (1962). 